\title{
Constituição da identidade infantil: significações de mães por meio de narrativas
}

\author{
Camila Turati Pessoa \\ Universidade Federal de Uberlândia - MG \\ Lúcia Helena Ferreira Mendonça Costa \\ Universidade Federal de Uberlândia - MG
}

\begin{abstract}
Resumo
Este artigo, à luz de Wallon e Vigotski, busca compreender como as mães significam suas infâncias, o ser mãe e as relações que estabelecem a respeito de suas infâncias e de seus filhos, bem como inter-relacionar estas significações com a constituição da identidade infantil. Participaram da pesquisa seis mães de crianças com idades entre três e seis anos, as quais foram entrevistadas individualmente por meio de questões semiestruturadas para investigar sobre a relação das mesmas e suas infâncias, o papel materno e suas relações com seus filhos. As mães, ao falarem de si, evidenciaram suas concepções sobre a infância e as interações com seus filhos e trouxeram como seus passados foram ressignificados pelo presente, na relação com seus filhos. São significações importantes para a constituição da identidade infantil e para a constituição das próprias mães. Desta forma, o contexto familiar constitui-se como um ambiente cultural e social que ajuda a explicar a multiplicidade dos sentidos atribuídos aos discursos das mães.
\end{abstract}

Palavras-chave: Infância; mães; Psicologia Histórico-Cultural.

\section{Children's identity constitution: the meaning of mothers in narratives}

\begin{abstract}
In this article we discuss how mothers make meaning of their childhoods and the relationships between their children, as well as how they relate these meanings to the way child's identity is constructed. Our research is supported by scholars such as Wallon and Vigotski . Our research reached six mothers of children between three and six years. The mothers were interviewed individually, using semi-structured questions which aimed to investigate them and their childhoods, the maternal role and their relationships with their children. Mothers when talking about themselves, revealed their ideas about their childhood, interactions with their children and how their pasts brought new meaning to their relationship with their children. These meanings are important for child identity as well as the identity of the mothers themselves. The family context, therefore involves a cultural and social environment that helps to explain the multiplicity of meanings in the discourses of the mothers.
\end{abstract}

Keywords: Childhood; mother; Cultural-Historical Psychology.

\section{Constitución de la identidad infantil: significaciones de madres por intermedio de narrativas}

\section{Resumen}

Este artículo, a la luz de Wallon y Vygotsky, busca comprender cómo las madres significan sus infancias, el ser madre y las relaciones que establecen a respeto de sus infancias y de sus hijos, así como inter-relacionar estas significaciones con la constitución de la identidad infantil. Participaron de la investigación seis madres de niños de edades entre tres y seis años, las cuales fueron encuestadas individualmente por medio de cuestiones semiestructuradas para investigar sobre las madres y sus infancias, el papel materno y sus relaciones con sus hijos. Las madres, al hablar de sí mismas, evidenciaron sus concepciones sobre la infancia y las interacciones con sus hijos y trajeron como sus pasados fueron resignificados por el presente, en la relación con sus hijos. Son significaciones importantes para la constitución de la identidad infantil y para la constitución de las propias madres. El contexto familiar se constituyó cómo un ambiente cultural y social que ayuda a explicar la multiplicidad de los sentidos atribuidos a los discursos de las madres.

Palabras-clave: Infancia; madres; Psicología Histórico-Cultural. 


\section{Introdução}

Este artigo insere-se na vertente de pesquisas que vem sendo desenvolvidas a respeito da temática "Processos de constituição do eu e do outro e suas inter-relações com a formação da identidade infantil em contextos educacional e familiar", à luz das perspectivas teóricas de Henri Wallon e Lev S. Vigotski. Relataremos aqui um recorte desta temática buscando contribuir para este campo.

Apoiamo-nos nas contribuições destes autores por compartilharem da mesma visão epistemológica a respeito do desenvolvimento humano, constituído na e pela interação social e inserido em um contexto histórico-cultural. Rochex (2002) reforça esta aproximação entre os autores dizendo que, tanto nas obras de Wallon como nas de Vigotski, encontra-se uma visão teórica e metodológica concernente com a concepção e a construção do objeto de estudo da Psicologia e de seus modos de conceitualização e de investigação, em que se postula a necessidade de uma abordagem global, qualitativa e dinâmica do psiquismo humano. Outra aproximação destes autores é evidenciada por Delaux (2002) quando afirma que ambos mostram que a oposição existente no desenvolvimento humano não se situa entre o individual e o social, mas sim, entre o biológico e o social.

Podemos dizer que, para estes autores, as relações sociais que estão na base da construção do conhecimento e do desenvolvimento humano como um todo se materializam nas redes de interações que acontecem em contextos culturais. Segundo Vigotski (1928/1998), nestes espaços são tecidos os significados e ações compartilhadas que favorecerão a constituição de sujeitos singulares e ao mesmo tempo múltiplos e inseridos no seu ambiente histórico-cultural. Mostrando a força do meio social e cultural, Wallon (1956/1975a) afirma que "as relações entre o ser e o meio enriquecem-se ainda pelo fato de o meio não ser constante e porque uma modificação do meio pode levar quer à supressão quer à transformação das pessoas que nele manifestam a sua existência" (p. 65).

Apreender como as mães significam suas infâncias, o ser mãe e as relações que estabelecem a respeito de suas infâncias e de seus filhos é o foco principal deste trabalho. Essas mães têm crianças pequenas que vivenciam momentos de desenvolvimento nos quais demarcam o interesse das crianças pelas interações com o adulto e com seus pares, momentos preciosos para a constituição do eu e do outro, e em especial, para a formação da identidade infantil.

Entendemos que dar voz às mães para retratarem suas histórias e pensar a relação de sua própria história de vida com a formação de seus filhos pode ajudar a repensar as relações família-criança/escola-criança e, especialmente, a conhecer a efetiva relação família-escola com base nas significações que as mães trazem a respeito de si, do outro e no que elas pensam sobre a constituição da identidade de seus filhos nos contextos familiar e escolar. Estas são instâncias de subjetivação infantil que podem favorecer a constituição da criança de forma completa, isto é, a criança olhada nos aspectos motriz, social, afetivo, intelectual e inserida em seu meio - enfim, a criança contextualizada.

Desta forma, as significações que as mães e os filhos trazem consigo são construídas numa determinada cultura, num ambiente social e culturalmente organizado, gestado nas e pelas interações sociais. O contexto familiar constitui-se como um ambiente cultural e social específico e dinâmico, o que explica a multiplicidade de sentidos subjacentes ao discurso das mães/pais. Assim, este é um dos contextos em que se encontram as várias possibilidades de significados importantes para o processo de subjetivação do sujeito. Essa constituição vem ao encontro do que entende Wallon (1956/1975b) quando enfatiza a constituição da identidade da criança através da diferenciação eu-outro, que nasce da imersão da pessoa no mundo social, nas relações e diálogos estabelecidos com o outro, consigo mesma e com o meio. Reconhecer um si mesmo passa, necessariamente, pela existência e também pelo reconhecimento de outros " $s i$ mesmos" (Vigotski, 2000).

O contexto familiar, representado neste trabalho por mães, é considerado por Wallon (1954/1975c) como um meio funcional de a criança começar a satisfazer todas as suas necessidades sob os critérios de sua própria família, ambiente em que a criança também aprende as suas primeiras condutas sociais. Para Szymanski (2006), é na família, enquanto meio social, que a criança encontra os primeiros "outros" e, com eles aprende o modo humano de existir ( $p$. 83). É através destas primeiras interações com o adulto que seu mundo adquire significado e ela começa a constituir-se como sujeito. Isto se dá na e pela troca intersubjetiva, por meio das relações afetivas, cognitivas e expressivas, que são o primeiro referencial para a sua constituição identitária. Essa identidade representa os diversos papéis de filho, aluno, amigo e outros. Estes processos são complexos, pois são coconstruídos pelos diversos atores sociais (família-criança-escola), sendo que, segundo Rossetti-Ferreira, Amorim e Oliveira (2009), os familiares interagem com seus filhos, organizando seus ambientes conforme suas concepções de desenvolvimento e de seus papéis. Tais concepções são formadas por meio de suas experiências de vida naquela cultura, aspecto que terá consequências para o desenvolvimento da criança.

\section{Os processos de constituição do eu e do outro: a formação da identidade infantil}

Pensar a criança pequena é pensá-la inserida, inicialmente, no contexto familiar enquanto um contexto de desenvolvimento, um meio social que favorece a constituição de sua pessoa. Segundo Vigotski (1996) e Wallon (1956/1975b), é por meio das interações da criança com o adulto e com os seus pares que ocorre a diferenciação do eu e do outro e assim se configura o eu infantil. Desta forma, são ampliadas as possibilidades da criança para afirmar e desenvolver cada vez mais a sua individualidade e para compreender melhor as relações sociais da cultura à qual pertence. É assim que 
a criança se constitui como uma pessoa distinta do outro e forma a sua identidade. Neste sentido encontramos também a escola e a família como corresponsáveis pela construção deste processo.

Para Wallon (1941/2002), os primeiros contatos entre a criança e o ambiente são de ordem afetiva. A sua comunicação se dá pelo diálogo tônico - portanto, é afetiva e acontece numa certa continuidade, pois a criança está unida ao outro, confundida com ela mesma, com as pessoas, com o meio ambiente. É pela interação que vai sendo possível esta diferenciação entre o "eu" e o "outro". Isto é importante para a formação da identidade infantil, pois muitas vezes esse "outro" não cumpre exatamente a função de continuidade, não responde de forma fundida, rompendo com os desejos da criança, frustrando-a e desafiando-a.

Ao nascer, a criança é tocada, cuidada pelos outros, e é nos movimentos destes "outros" que as suas primeiras atitudes vão tomar forma. Por meio do atendimento às suas necessidades fisiológicas e emocionais é que os seus gestos, as suas atitudes, a sua fisionomia e a sua voz passarão do domínio impulsivo ao expressivo, provocando outras formas de atendimento naqueles que cuidam dela.

Segundo Wallon (1941/2002, 1956/1975b), é por volta dos três anos de idade que a criança terá mais autonomia, maior possibilidade de afirmar o seu ponto de vista. Nesse momento ela deixa de designar-se na terceira pessoa e passa a referir-se a si pelo pronome pessoal "eu", opondo-se sistematicamente ao que é diferente dela, o "não-eu", além de ostentar os pronomes "meu" e "minha". Agora o que interessa para a criança são as relações com as pessoas. Ela recusa, afronta o outro, combate as ordens, pela simples razão de experimentar a sua própria autonomia. Com a conduta de oposição a criança busca a propriedade das coisas pelo desejo de competição, em que ela procura apropriar-se do que pertence aos outros geralmente sob a forma de protesto contra a partilha.

As interações sociais, os exercícios e os jogos são recursos importantes para que a criança consiga dissociar, nas impressões, o que lhe pertence ou não, provocando em si manifestações de espera, frustração, raiva, alegria, explosão de surpresa. É o outro que vai exigir da criança, por meio do confronto da gestualidade e da palavra, formas diferenciadas de ações e reações, porque os objetos e as pessoas rompem expectativas e este rompimento é importante neste processo de diferenciação do eu e do outro.

A diferenciação do eu e do outro é que configurará o eu infantil, alargando as possibilidades da criança para afirmar cada vez mais a sua individualidade e compreender melhor as relações sociais da cultura à qual pertence. Não obstante, essa diferenciação de si mesma e do outro é confusa, ameaçadora e ao mesmo tempo "elemento de estruturação do eu, naquilo que Ihe opõe o não-eu" (Werebe, \& Nadel-Brulfert, 1986, p.16). Neste sentido, a experiência na família e nos centros de educação tem uma relevância crucial no processo de formação infantil, pois é nestes contextos diversos que a criança expressa o seu eu, alternadamente, confundindo-se com ele e dele se dissociando, a ele opondo-se e identificando-se. Assim, compreender que a oposição, a sedução e a imitação ao outro são crises interacionais propulsoras do desenvolvimento infantil, e que é papel dos pais e do educador compreender a criança e ajudá-la a utilizar diferentes estratégias em suas interações, propiciará a ampliação e diferenciação do eu e do outro e a construção de identidade infantil.

Dentre as várias contribuições de Vigotski, evidencia-se a ideia central de que o homem constitui-se em sua humanidade na relação com o outro e de que a criança, ao nascer, herda toda a evolução da espécie e da cultura. Para esse renomado autor, desde os primeiros dias de desenvolvimento da criança suas atividades adquirem um significado próprio, num sistema de comportamento social enraizado nas ligações entre história individual e história social.

Neste sentido, Vigotski (2000) concebe o homem como "uma personalidade social, ou seja, o conjunto de relações sociais, encarnado no indivíduo (funções psicológicas, construídas pela estrutura social)" (p. 33). Assim, o indivíduo apreende o significado das atividades humanas de sua cultura pela experiência vivenciada com os outros, pelos objetos que substanciam suas atividades anteriores e pela sua própria história de ação nesses objetos com os outros.

Vimos também no Manuscrito de 1929 (Vigotski, 2000) que o "sujeito da relação" não é o mesmo em todas as relações sociais. A posição que ele ocupa em cada uma delas varia em conformidade com o tipo de relação. Neste sentido, o autor discute que se as posições do sujeito social variam em função do outro sujeito da relação, a pessoa social envolvida em todas as relações permanece a mesma. Esclarece que "a ideia de pessoa social envolve a idéia ao mesmo, de unidade e de multiplicidade, o que coloca em xeque o conceito tradicional de sujeito psicológico" (p.73).

Nesta direção, o autor também destaca a importância das interações na constituição da pessoa, entendida esta como um indivíduo social, real e concreto, cuja singularidade se constitui enquanto membro de um grupo social-cultural específico. Essa constituição é pensada como um processo em que o mundo cultural apresenta-se ao sujeito como o outro, e a referência externa permite ao ser humano constituir-se como tal. Desta forma, afirma que "(...) nos tornamos nós mesmos através dos outros” (Vigotski, 2000, p.57).

Toda relação é social, ou seja, a relação se dá entre um eu e um outro. As pessoas vão se constituindo numa rede de relações diferentes, em contextos específicos, concretos e em tempos históricos distintos, e estão sempre em contato permanente e íntimo com o outro, o socius de que fala Wallon (1954/1975c). Para ele "o socius ou o outro é um parceiro perpétuo do eu na vida psíquica. É normalmente reduzido, inaparente, contido e como que negado pela vontade de dominação e de integridade completa que acompanha o eu (....)" (p. 159). Vale destacar que o "socius" deve ser considerado como todas as interações significativas que o sujeito tem com o outro, pois somente participarão de sua constituição as apropriações que faz para si das relações com o outro de modo a fazer sentido para o sujeito. Nem todo "outro" com o qual interagimos é constitutivo do "eu", 
mas só aquelas relações realmente significativas, as quais serão internalizadas.

Destarte as mães neste estudo assumem o papel do outro para a criança em constituição, e com isso elas próprias estão ao mesmo tempo criando significados para essa relação. A significação surge, então, na própria relação, e podemos dizer que o que é internalizado são as significações dessas interações. Neste sentido, este estudo objetiva investigar as narrativas de mães, num primeiro momento, fazendo perguntas interligadas, a saber: "Quais são as significações que as mães atribuem às suas infâncias?"; "Quais são as relações que estabelecem a respeito de suas infâncias e a de seus filhos?". Num segundo momento, a partir destes preceitos procuraremos inter-relacionar essas significações construídas pelas mães com a constituição da identidade das crianças no espaço da família.

\section{Método}

O método que adotamos é a pesquisa qualitativa. Buscamos compreender as questões deste trabalho de modo a valorizar a individualidade e a riqueza das narrativas das mães, e neste sentido, González-Rey (2002) traz que, para o estudo da subjetividade humana, é necessário uma epistemologia que contemple estes aspectos. Este tipo de pesquisa entende que o estudo do ser humano e de suas significações exige um olhar atento à produção da singularidade que é formada de modo simultâneo pela interação das subjetividades social e individual, resultando em um processo dialógico.

Nesta perspectiva, não buscamos construir respostas generalistas ou mesmo simplistas sobre os sujeitos, mas compreender a complexidade da construção destas relações e produções humanas (González-Rey, 2002). Diante disto propusemo-nos a conhecer as mães por meio de suas narrativas, com base nas significações que elas atribuem às suas infâncias e nas relações que se referem a respeito de suas infâncias e a de seus filhos.

Participaram desta pesquisa seis mães de crianças, com idades entre três e seis anos, que frequentam instituições de ensino público em uma cidade do Triângulo Mineiro - MG. A escolha foi feita de modo aleatório, por meio de indicação das próprias instituições de ensino, sendo a única exigência ter filhos na faixa etária citada acima. Esta exigência vai ao encontro do referencial teórico no qual nos apoiamos ao compreendermos a constituição da identidade infantil, sendo esta faixa etária privilegiada com momentos ricos de interações, de diferenciação eu-outro (Wallon, 1954/1975b) e de formações qualitativamente novas na personalidade da criança (Vigotski, 1996).

Para o registro dos dados foram realizadas entrevistas individuais com cada mãe em horário e local previamente agendados, as quais foram gravadas em aparelho de áudio, com o consentimento de cada participante. As entrevistas foram elaboradas em formato semiestruturado, partindo das premissas da pesquisa qualitativa para possibilitar um hiato entre o que almejamos conhecer e o que o sujeito deseja relatar (González-Rey, 2002). O roteiro das entrevistas baseou-se em perguntas norteadoras para a construção das narrativas e versou, em um primeiro bloco, sobre as mães e suas infâncias e, posteriormente, sobre o papel da mãe e suas relações com seus filhos.

Para realizar a análise dos dados construídos, primeiramente foram feitas transcrições na íntegra de cada entrevista, e num segundo momento, uma leitura minuciosa de cada uma, a que se seguiu a identificação dos conteúdos que correspondiam aos nossos objetivos. Depois recorremos a Aguiar e Ozella (2006) para analisar os conteúdos identificados, buscando que se evidenciassem similaridade, complementaridade e contraposição, apresentando trechos que melhor ilustrassem estes itens. Na última etapa da análise buscamos inter-relacionar essas significações construídas pelas mães com a constituição da identidade das crianças no espaço da família, à luz das perspectivas teóricas de Wallon e Vigotski. A seguir, apresentaremos a análise e a interpretação dos dados construídos na pesquisa.

\section{Análise e interpretação dos dados}

Num primeiro momento analisamos os conteúdos referentes ao que cada mãe narrou sobre sua infância, quando trouxeram à fala eventos que foram significativos e alguns sentidos elaborados ao construírem suas narrativas. Narraram fatos como as primeiras memórias que vêm à mente quando pensam sobre suas infâncias, quem foram seus parceiros de interação e como foram suas relações com seus pais. No segundo momento foi possível apreender o que as mães retrataram a respeito do "ser mãe", quais as mudanças que este papel implicou em suas vidas e quais relações estabelecem com suas infâncias ao pensarem as infâncias de seus filhos.

Ao analisar estas narrativas, procuraremos também entrelaçar as significações que as mães foram construindo a respeito de suas infâncias, as que seus filhos foram construindo e a constituição da identidade infantil, segundo o nosso referencial teórico.

\section{Sobre as mães e suas infâncias: constituição de si e do outro}

As mães ${ }^{1}$ Rita, Cláudia, Valéria, Márcia, Adriana e Cristina têm entre 21 e 33 anos de idade. Rita viveu com os pais e dois irmãos durante a infância, sendo seu irmão mais velho seu principal parceiro de interação. Ela tem duas filhas que considera "tudo em sua vida". Cláudia também brincava com seus irmãos quando criança, pois seus pais tinham um sítio. Hoje tem três filhos e vive com eles. Valéria viveu com seus pais e com a irmã durante a infância e foi criada praticamente por esta última. Hoje tem um filho que é prioridade

1 Nomes fictícios para preservar a identidade das participantes. 
em sua vida. Márcia morou com os pais quando criança, tem sete irmãos e começou a trabalhar aos catorze anos. Hoje tem dois filhos e adora ser mãe. Adriana tem cinco irmãos e cuidava deles quando crianças. Brincava com eles, mas começou trabalhar aos oito anos. Hoje tem três filhos e adora curtir a infância deles. Cristina viveu sua infância com sua mãe e brincava com os primos quando pequena; hoje tem uma filha que mudou tudo em sua vida.

As infâncias foram revividas pelas mães e ao serem recontadas, trouxeram marcas de sofrimentos causados por vícios, brigas, separação dos pais e mudança de residência, como se pode perceber na similaridade das seguintes falas:

“[...] meu pai era muito alcoólatra, então ele brigava muito, meu pai e minha mãe, [...] ele simplesmente botou fogo na casa, aí daí pra frente que minha vida começou a mudar, fui morar com meus avós." (Valéria).

"Meu pai começou a trair minha mãe, sempre quem pegava ele era eu." (Márcia).

Notamos uma complementaridade das falas sobre esta fase da vida, marcada por momentos complexos também na fala de Adriana, que relatou ter tido uma infância difícil, por ter que assumir papéis que não eram esperados para uma criança, tendo que cuidar dos irmãos quando ainda muito nova:

"Nada fácil, porque eu sou a segunda filha de cinco irmãos. Então, meninas, eu sou a mais velhas das meninas [...], então assim, eu era mãezona dos irmãos, eu com oito anos eu já trabalhava pra ajudar minha mãe com meus irmãos."

De algum modo, as narrativas sobre estas infâncias misturam eventos inevitáveis, como ter que cuidar dos irmãos e enfrentar separação dos pais juntamente com vivências que aconteceram concomitantemente e de algum modo caracterizam também estas infâncias. Estes conflitos vivenciados trazem marcas e são constitutivas do modo como significam o ser criança, uma vez que, segundo Wallon (1975), é na família que a criança apreende as primeiras formas de interação social. O contexto familiar constitui um ambiente cultural e social que explica a multiplicidade de sentidos dos discursos das mães, como ficou evidenciado nas falas acima.

É importante ressaltar que Valéria e Márcia deixam claro que a infância dolorosa relacionou-se ao convívio com os pais, e nos apresentam outros aspectos que marcaram saudosamente esta fase, evidenciando memórias que se aproximam de uma infância marcada por brincadeiras. Destacam elementos como o brincar com os irmãos, com colegas, a relação prazerosa com os objetos e ainda o bem-estar ao viverem em contextos educacionais:

"Eu tinha muita amiga, eu gostava de ir pra escola, adorava escola. Minha irmã também me levava muito pra passear, sabe, me dava muito brinquedo..."(Valéria).
"Foi ótima minha infância, brincava muito, tinha muito colega, tudo de bom que você pensar que teve uma infância, assim pra uma criança, eu tive." (Márcia).

Rita, Cláudia e Cristina relataram uma infância que Ihes traz boas lembranças, semelhantes às memórias saudosas das mães acima relatadas, e descrevem eventos como brincadeiras na rua, em sítios, interações com os pais, com os irmãos e liberdade ao ser criança. São relatos de memórias sobre o que mais gostavam de fazer:

"Minha infância foi ótima! [...] Brincava muito na rua, corria muito na rua, brincava de subir em árvores... de tudo de bagunça, eu aproveitei!" (Rita).

"Eu brincava com os meus irmãos, meus pais tinham um sítio e eu gostava muito de ir pra lá sabe? Brincava no meio do mato... essas coisas." (Cláudia).

"Olha, foi muito boa [...] eu não tenho um pai presente, minha mãe sempre esteve do meu lado, e eu tento fazer a mesma coisa com ela. Com a minha filha entendeu, ficar do lado... Eu morava perto da minha avó também..." (Cristina).

Vemos então que as narrativas ao mesmo tempo se aproximam e se distanciam, delineando as infâncias singulares de cada uma. Rita e Cláudia enfatizam a infância como "memória saudosa" devido às brincadeiras e às relações com os pares; já Cristina a apresenta como "boa", referindo-se às relações com a mãe e avó. Tais significações fortalecem o enfoque histórico-cultural, no qual o sujeito é constituído nas relações com o outro e com seu meio, apropriando-se da cultura em que está inserido.

Em suas falas, as mães relatam o brincar construindo memórias que marcam esta época da vida, com brincadeira de papéis, de roda, de boneca, de casinha; por outro lado, comparando suas infâncias com as de seus filhos em relação à liberdade que sentiam ao serem crianças, afirmam que nos dias de hoje não sentem que seja possível ter uma infância como a que viveram. Ainda aproximam estes destaques como ponto fundamental para o ser criança, apresentando similaridade em suas narrativas:

“(Brincava com) Irmãos. E com os amigos que a gente tinha... E nossa, era muito bom, a gente divertia demais! [...] Brincava bastante, tinha liberdade total que hoje não tem, né? [...] brincando mesmo na rua de terra... chovia e escorria água e a gente brincava muito ali naquela poça d'água da chuva... eu, meus irmãos." (Rita).

"(Brincava) De casinha, uma das minhas brincadeiras preferidas. Brincar de casinha, de roda... a gente brincava muito de roda. Bem diferente de hoje, né?" (Cláudia).

Ao falarem sobre seus pares de interação, elas os apresentam como figuras importantes, que participavam destes momentos e interagiam com elas de modo a marcar 
suas infâncias, sendo estes parceiros de interação seus primos, irmãos e amigos. Mais uma vez salientamos a importância do outro na constituição do eu, em especial da criança:

"(Brincava) Com meus primos, na mesma casa... [...] tudo no mesmo quintal. Brincava em árvores, coisas de criança." (Cristina).

"Brincava com amigos, irmão, irmã... eu brincava mais com minhas colegas." (Márcia).

Já a relação com os pais aparece de vários modos, sendo a interação tanto de proximidade como verticalizada, em que o respeito significava, por vezes, não envolver-se em sentido amoroso ou não participar de brincadeiras. As falas tanto são similares como totalmente opostas, pois as figuras materna e paterna assumem significados diferentes para estas mães, relatando tanto pais presentes e atenciosos como pais que eram distantes e não brincavam com seus filhos:

"[...] com a minha mãe, sempre muito grudada com a minha mãe. [...] Sempre me dava atenção, tudo que eu precisava, posso contar com a minha mãe, perguntar... porque criança é muito disso". (Cristina).

"Ah... de respeito, de receio, de medo... mas era boa. [...] Não, não. Eles não brincavam. [...] Ah minha mãe sempre foi muito brava. Brava demais. Meu pai era muito fechado; era não, é até hoje. Eles não brincavam com a gente não." (Cláudia).

A escola, espaço privilegiado de interações tanto entre os pares como com adultos mediadores da cultura, também aparece como local de lembranças boas para as mães. Relatam este local como lócus de apoio representado pela figura de professores que interferiram em suas infâncias, sentindo-se cuidadas e acolhidas, como podemos ver na fala de Valéria:

"Ai, eu lembro da minha professora... é.. assim... ela... eu ia sempre de moletom, porque minha mãe me espancava muito, e ela ficava sempre me perguntando, o que tá acontecendo [...] minha professora era muito minha amiga, perguntava o que tava acontecendo em casa, sabe?"

Neste primeiro momento percebemos as memórias marcantes, as brincadeiras, as experiências com os pares, como era a relação com os pais e ainda as memórias sobre a escola para estas participantes. Pode-se dizer que as infâncias foram reconstruídas ao serem contadas, pois ficaram evidenciados os recortes que cada uma fez sobre essa época de sua vida, emergindo os sentidos colocados nestas narrativas como infância boa, dolorosa, prazerosa, cuidada e com o acolhimento de pessoas de referência, quando necessário.
As falas tanto se aproximaram, demonstrando similaridade e complementaridade, como se distanciaram, deixando emergir certas contraposições que não deixam de contar a qual lugar estas mães estão se referindo ao falarem de suas trajetórias de vida. Nas interações com pares e com o adulto expressaram os diversos significados que têm dos objetos e do outro, o que proporciona uma diferenciação entre estes e ao mesmo tempo traz suas significações sobre o que consideram importante para a infância.

\section{Sobre o papel da mãe e suas relações com seus filhos}

Perguntamos nesse momento da entrevista como foi vivenciar o "ser mãe", e elas afirmaram que é uma fase ótima, apresentando similaridade em suas falas, apontando que gostam muito deste papel, que se sentiam abençoadas por terem as crianças, também porque sentiam a responsabilidade de tornar-se mãe e a ansiedade e o desejo ao aguardarem o filho que gestavam. Destacam:

"Nossa! Foi a melhor coisa do mundo! Eu planejava e todo mês eu ficava esperando que o neném ia chegar... e quando chegou foi uma bênção! [...] antes de saber o sexo eu já tinha escolhido o nome... e foi muito bom! É até hoje muito bom." (Cláudia).

"Ai, é muito bom! [...] Acho que ser mãe não tem explicação, porque pra quem quer ser mãe é um sonho realizado. [...] E é uma responsabilidade muito grande também, pelo que a gente tá vivendo, o mundo que a gente tá vivendo, [...] que a gente tem que ter a cabeça no lugar, conversar muito, educar e criar. [...] Se pudesse ficar desse tamanhozinho pra vida e não crescer era bom demais." (Márcia).

Nesta última fala Márcia afirma que gostaria que seu filho menor fosse pequeno por um bom tempo, o que podemos inferir pelo fato de sua infância ter sido vivenciada de modo "encurtado", como ela relatou no primeiro momento da entrevista, e por ter sido um período difícil. Percebemos que hoje ela valoriza a infância de seus filhos, pois traz contraposição à sua história e busca oferecer a seus filhos a infância que não teve. As entrevistadas também relatam surpresas ao ser mãe, gerando mudança e aprendizado e exigindo outras formas de lidar com a nova situação:

\section{"Ai... assim... igual eu te falei... assim, eu queria ter minha família, como eu não tive, eu queria ter, sabe, era o que eu mais queria, [...] eu levei muito susto, porque eu nunca tinha pegado nenhum bebê, não tinha trocado fralda..." (Valéria).}

Outro ponto importante que apareceu nas conversas foi como o ser mãe permitiu reelaborar o passado como filha e vivenciar o presente pensando a infância do próprio filho, trazendo similaridade e aproximações quando relataram 
suas histórias para pensar como auxiliarão na construção da de seus filhos:

"Depois que eu fui mãe é que eu vi o que era ser mãe. [...] Aí eu prestei mais atenção ainda, [...] E quando eu tive minha filha foi isso, me veio à cabeça tudo que minha mãe fez comigo [...] então eu comecei a observar o que minha mãe tinha passado ainda mais com quatro filhos, e eu com uma só, imagina ela." (Cristina).

"[...] procuro dedicar mais pra elas meu tempo, minha vida, tudo pra elas assim. Uma coisa que minha mãe e meu pai não teve, tempo. Hoje eu dedico ao máximo pra elas assim, de ficar mesmo com elas, brincar com elas, tudo. Ter elas é tudo pra mim. Pra mim é tudo!" (Rita).

Esta tentativa de fazer diferente, de oferecer aos fiIhos o que não tiveram na própria infância, também é conteúdo evidenciado pelas mães, complementando com as falas já apresentadas, pois trazem elementos de como buscam oferecer esta infância e como gostariam de tê-la vivenciado. Salientam o final de semana como momento importante para interagir com seus filhos, pois têm mais tempo, buscam oferecer a seus filhos momentos que tragam a elas lembranças da felicidade e alegria de quando eram crianças, e ainda destacam a liberdade como fundamental na construção de uma infância:

"[... não tenho uma boa lembrança de ter saído com a minha mãe um dia. Eu não passo um final de semana na minha casa sem eu sair com meus filhos. Não passo." (Adriana).

"[...] eu procuro dar a elas a felicidade que eu tive, de brincar, de correr na água, de correr na terra, de tudo isso [...] Eu procuro dar a elas isso que eu senti feliz naquela época... Eu dou essa liberdade delas estar brincando na terra, de correr na água da chuva. Tudo eu dou pra elas essa liberdade e elas amam, amam isso também. Essa liberdade também elas adoram." (Rita).

Neste segundo momento da entrevista percebemos que o fato de ser mãe representa para cada uma delas uma nova fase da vida, colocando os filhos em primeiro plano e pensando primeiro no crescimento deles. Também referiram que, ao se tornarem mães, puderam repensar sua posição enquanto filhas, revivendo o passado e trazendo-o para o presente. Outro ponto que enriquece a discussão sobre a constituição do ser humano é que buscam oferecer aos fiIhos o que acreditam ser o melhor para a infância deles, o que aparece de modo semelhante em todas as falas.

Assim, compreendemos que as narrativas das mães sobre sua infância, sobre ser mãe e sobre suas relações com seus filhos evidenciam as significações que elas construíram em relação à própria infância e como estes processos se inter-relacionam com as histórias dos seus filhos. A forma como as mães significaram sua própria infância tem a ver com o modo como interagem, significam e veem suas rela- ções com estes, de modo que a significação surge na própria relação. As diversas formas de olhar estas interações são importantes para a constituição da identidade infantil, uma vez que a pessoa vai se constituindo numa rede de relações diferentes e em contextos específicos e concretos.

\section{Sobre as significações de infância e a constituição da identidade infantil}

Compreender a constituição da identidade infantil, na perspectiva de Wallon e Vigotski, passa necessariamente pelas interações com os pares e com os adultos. É por meio destas interações que a pessoa se constitui e se diferencia como distinta de outrem. Esta pessoa é entendida como um sujeito social, real e concreto, cuja singularidade se forma enquanto membro de um grupo social-cultural específico.

Esse processo de construção da identidade iniciar-se-á mais acirradamente por volta dos três anos de idade, momento em que as crianças buscarão, por meio de suas interações, construir o seu eu a partir do outro, aquele que "não sou eu", o que Wallon (1956/1975b, 1993) denominou de não eu. Desta forma, as interações sociais, os exercícios e os jogos são recursos importantes para que a criança consiga dissociar nas impressões o que the pertence ou não. É outro que vai exigir da criança, através do confronto da gestualidade e da palavra, formas diferenciadas de ações e reações. É este processo lúdico que permite a construção de posicionamentos diversos por meio dos quais a criança vai se diferenciando e formando a sua individualidade, a sua identidade.

Entendemos, então, que este movimento de constituição da identidade se dá também no contexto familiar, onde a criança encontra os primeiros "outros" e com eles aprende o modo humano de existir. As interações das mães com seus filhos revelam elementos de que elas se apropriaram ao vivenciarem a própria infância, e o passado é re-significado pelo presente nas interações delas com seus filhos.

Destacamos aqui alguns elementos destas narrativas que nos ajudam a inter-relacionar estas significações com a constituição da identidade infantil. As falas nos remetem a alguns preceitos que se relacionam diretamente com aspectos da constituição desta identidade e que percebemos estarem presentes nas relações das mães com seus filhos.

Um primeiro preceito é a questão do tempo que passam com seus filhos. As mães apontam a importância de reservar um momento para estarem com seus filhos e interagir com eles, construindo relações de trocas entre adulto e criança que de alguma forma contribuem para que a identidade infantil se fortaleça e se desenvolva. Tivemos tanto relatos de mães que tiveram este tempo com seus pais quando crianças como de mães que não o tiveram, mas todas são concordantes ao trazerem esta valorização. Percebemos que o enfoque histórico-cultural mais uma vez corrobora esta compreensão no sentido de valorizar a interação com os pares, destacando a família como a primeira instância so- 
cializadora e o meio social e cultural como constitutivo das significações evidenciadas no posicionamento de cada mãe.

O brincar foi outro preceito que se destacou nas entrevistas. Em seus próprios relatos sobre quando eram crianças elas narram memórias saudosas e prazerosas sobre suas brincadeiras, o que, ao refletirem sobre a infância de seus filhos, as faz considerar esta atividade como a principal na infância deles. Destacam a necessidade de a criança possuir um repertório de atividades que a auxilie em sua aprendizagem e desenvolvimento por meio de ações consigo mesma e com os pares, incorporando e elaborando a cultura ao seu redor. As mães então valorizam a brincadeira e podemos inferir que buscam proporcionar estes momentos a seus filhos no intuito de interferir intencionalmente na formação deles e na constituição de suas identidades.

Relacionar-se com os pares é outro aspecto de que as mães destacam como muito importante, enfocando tanto a presença como a interação da criança com eles. São considerados por elas principalmente como crianças que interagem com seus filhos, sendo provenientes tanto do ambiente familiar - como irmãos e primos - quanto de espaços de interação com colegas e vizinhos - como a escola e os contextos ao redor da criança. O enfoque teórico-metodológico que aqui consideramos infere que os pares são aqueles que se relacionam com o sujeito de modo a constituí-lo dialeticamente nas e pelas relações e pela interiorização do meio pelo sujeito. Assim, além de parceiros da mesma idade, propiciar interações com adultos e com pessoas em diversos contextos também favorece a constituição desta identidade.

Por fim, observamos a expressividade e a criação, destacadas indiretamente pelas mães como importantes para a constituição da identidade infantil. Ao afirmarem que a criança precisa brincar, inventar e interagir com seus pares e com o contexto no qual está inserida, as mães enfatizam que a criança deve experimentar e socializar a seu modo. Este aspecto perpassa as relações das mães com seus filhos e ainda interfere diretamente no modo como estas Ihes propõem atividades e se relacionam com eles. Pode-se dizer ainda, levando em consideração estes aspectos, que as mães modificam e reelaboram seus modos tanto de ver a infância como de preparar e oferecer a seus filhos trocas e relações, incidindo em suas constituições como seres humanos.

\section{Considerações finais}

O principal foco deste trabalho consistiu em apreender como as mães significam suas infâncias, o ser mãe e as relações que estabelecem a respeito de suas infâncias e de seus filhos. A partir destas significações procuramos compreender suas inter-relações com a constituição da identidade infantil à luz das perspectivas teóricas de Wallon e de Vigotski. Para estes autores, é nas e pelas interações que o sujeito se constitui. Afirmam ainda que as relações sociais, enquanto base da construção do conhecimento e do desenvolvimento humano, materializam-se nas redes de interações inseridas em contextos culturais distintos. Neste sentido, as mães desta pesquisa assumem o papel do outro para a criança em constituição, e com isso elas próprias estão ao mesmo tempo criando significados para essa relação e constituindo-se como mães. As significações evidenciadas surgiram no contexto social e na própria relação de cada mãe consigo mesma, com suas histórias, com os familiares, com os filhos e com os amigos.

Ao falarem de suas histórias as mães trouxeram lembranças boas e ruins e destacaram o que consideravam importante para seus filhos, evidenciando suas concepções sobre infância. Estas significações são constitutivas da formação de cada uma delas e, consequentemente, influenciam o modo como significam a condição de criança, o modo como interagem com os seus filhos e o que buscam oferecer a eles. Para Wallon (1954/1975c), é na família que a criança apreende as primeiras formas de interação social. Assim, o contexto familiar constitui-se como um ambiente cultural e social que explica a multiplicidade de sentidos atribuídos aos discursos das mães.

É neste âmbito que este estudo dá importância à escuta de mães, pois entendemos que a identidade infantil se constitui a partir do processo de diferenciação entre o "eu e o "outro", ou seja, quando a criança diferencia o "eu" do "não eu". Este processo nasce da imersão da pessoa no mundo social, nas relações e diálogos estabelecidos com o outro, consigo mesma e com o meio.

A forma como as mães se relacionaram com seus filhos influencia a maneira como a criança se vê e se relaciona com os outros em seus diversos contextos. Pode-se ilustrar a questão do brincar por seu destaque como uma atividade fundamental para a aprendizagem e desenvolvimento da criança, e, principalmente para a construção de relações afetivas. Estas relações se materializam nas brincadeiras com irmãos, primos, colegas e adultos, enriquecendo o processo formativo da criança. As interações das mães com seus filhos trouxeram elementos de que elas se apropriaram ao vivenciarem sua infância, e seu passado foi ressignificado no presente, isto é, nas interações delas com seus filhos.

Os diversos papéis de filho, aluno, amigo e outros favorecem a formação da identidade infantil e são constituídos pelos diversos atores sociais, como a família, a criança e a escola. A forma como a escola e os familiares - especialmente as mães - interagem e organizam seus ambientes retrata suas concepções, suas crenças e seus papéis em relação aos alunos/filhos.

Neste sentido, a escola é outro contexto importante para a criança afirmar-se e tomar consciência de que sua pessoa é diferente de qualquer outra. As interações neste contexto ampliam o olhar da criança, dos familiares, dos educadores e permitem a construção de posicionamentos diversos por meio dos quais a criança vai se diferenciando e formando a sua individualidade, a sua identidade.

Por fim, esta pesquisa pretendeu contribuir também com as discussões dos profissionais da Educação - entre eles o psicólogo escolar - no sentido de compreenderem o 
lugar ocupado por mães, pais e responsáveis na formação da criança. Conhecer como estes familiares - especialmente as mães - interagem com seus filhos em seus contextos e como estas vivências chegam até as instituições escolares pode favorecer diálogos mais estreitos com a escola no tocante à Educação Infantil. Saber das significações que mães e demais familiares atribuem às suas infâncias, seus papéis e concepções, pode enriquecer as interlocuções entre os principais espaços de constituição infantil: a família e a escola. Sugerimos, então, que se desenvolvam outras pesquisas neste âmbito, visando aprofundar as reflexões sobre o tema justamente para contribuir na construção de saberes que envolvem estes campos e incidem diretamente na vida dos sujeitos, na atuação dos profissionais da área e, consequentemente, na Educação.

\section{Referências}

Aguiar, W. M. J., \& Ozella, S. (2006). Núcleos de significação como instrumento para a apreensão da constituição dos sentidos. Revista Psicologia, Ciência e Profissão, 26 (2), 223-244.

Delaux, M. (2002). Vygotski, Wallon et lês débats actuels sur la théorie de la pensée. Em Clot, d'YVES. Avec Vygotski. (pp. 105-120). (Traduzido do Russo para o Francês) 12 ed. La Dispute/SNÉDIT: Paris.

González-Rey, F. L. (2002). Pesquisa qualitativa em Psicologia caminhos e desafios. São Paulo: Pioneira Thompson Learning.

Rochex, J. Y. (2002). Vygotski et Wallon: Pour une pensée dialectique des rapports entre pensée et affect. Em Clot, d'YVES. Avec Vygotski (pp. 121-139). (Traduzido do Russo para o Francês) 12 ed. La Dispute/SNÉDIT: Paris.

Rossetti-Ferreira, M. C, Amorin, K. S., \& Oliveira, Z. M. R. (2009). Olhando a criança e seus outros: uma trajetória de pesquisa em educação infantil. Psicologia USP. 20, (3), 437-464.
Szymanski, H. (2006). Práticas educativas familiares e o sentido da constituição. Paidéia USP Ribeirão Preto, 16, (33), 81-90.

Vigotski, L. S. (2000). Manuscrito de 1929. Educação \& Sociedade, 71, (pp. 21-44).

Vigotski, L. S. (1998). El desarrollo cultural del niño y otros textos inéditos. Buenos Aires: Almagestos. (Trabalho original publicado em 1928).

Vigotski, L. S. (1996). Obras escogidas IV. Madrid, Centro de Publicaciones del MEC y Visor Distribuiciones.

Wallon, H. (1993). La crise de personnalité (3 ans). Affirmation Du moi et objectivité. Em Wallon, H. Les origines Du caractere chez l'enfant. (3 ed, pp. 285-291). Paris: Quadrige.

Wallon, H. (1975a.). Psicologia e materialismo dialético. Em Wallon, H. Objetivos e Métodos da Psicologia. Lisboa: Editorial Estampa. (Trabalho original publicado em 1956).

Wallon, H. (1975b.). As etapas da personalidade na criança. Em Wallon, H. Objetivos e Métodos da Psicologia. Lisboa: Editorial Estampa. (Trabalho original publicado em 1956).

Wallon, H. (1975c). Os meios, os grupos e a psicogênese da criança. Em Wallon, H. Psicologia e educação da infância (antologia). Lisboa: Estampa. (Trabalho original publicado em 1954).

Wallon, H. (2002). L'evolution psychologique de l'enfant. (11.ed). Paris: Armand Coin Éditeur. (Trabalho original publicado em 1941).

Werebe, M. J. G., \& Nadel-Brulfert, J. (Orgs.). (1986). Henri Wallon. São Paulo: Ática.

\section{Sobre as autoras}

Camila Turati Pessoa (camilatpessoa@gmail.com)

Universidade Federal de Uberlândia, Mestre em Psicologia.

Lúcia Helena Ferreira Mendonça Costa (luciahfmcosta@hotmail.com) Universidade Federal de Uberlândia, Pós- Doutora em Psicologia. 